\title{
(8)
}

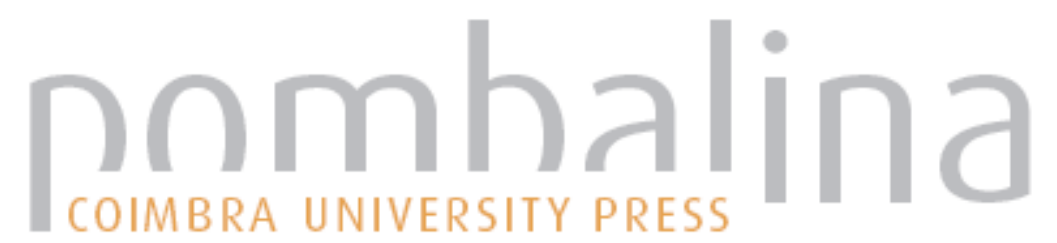

\section{Suicide by drowning after Bromazepam intoxication: a case report}

\begin{tabular}{|c|c|}
\hline Autor(es): & $\begin{array}{l}\text { Proença, P; Vidinha, J.; Teixeira, H.; Mustra, C.; Cortesão, L.; Franco, J.; } \\
\text { Corte-Real, F.; Vieira, D. N. }\end{array}$ \\
\hline Publicado por: & Imprensa da Universidade de Coimbra \\
\hline $\begin{array}{l}\text { URL } \\
\text { persistente: }\end{array}$ & URI:http://hdl.handle.net/10316.2/31730 \\
\hline DOI: & DOI:http://dx.doi.org/10.14195/978-989-26-0173-1_76 \\
\hline Accessed: & 26-Apr-2023 11:31:10 \\
\hline
\end{tabular}

A navegação consulta e descarregamento dos títulos inseridos nas Bibliotecas Digitais UC Digitalis, UC Pombalina e UC Impactum, pressupõem a aceitação plena e sem reservas dos Termos e Condições de Uso destas Bibliotecas Digitais, disponíveis em https://digitalis.uc.pt/pt-pt/termos.

Conforme exposto nos referidos Termos e Condições de Uso, o descarregamento de títulos de acesso restrito requer uma licença válida de autorização devendo o utilizador aceder ao(s) documento(s) a partir de um endereço de IP da instituição detentora da supramencionada licença.

Ao utilizador é apenas permitido o descarregamento para uso pessoal, pelo que o emprego do(s) título(s) descarregado(s) para outro fim, designadamente comercial, carece de autorização do respetivo autor ou editor da obra.

Na medida em que todas as obras da UC Digitalis se encontram protegidas pelo Código do Direito de Autor e Direitos Conexos e demais legislação aplicável, toda a cópia, parcial ou total, deste documento, nos casos em que é legalmente admitida, deverá conter ou fazer-se acompanhar por este aviso.

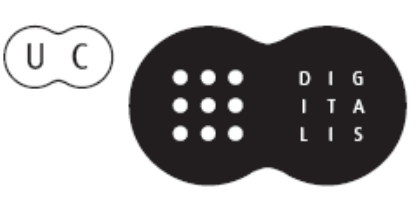




\section{Duarte Nuno Vieira Anthony Busuttil \\ Denis Cusack • Philip Beth}
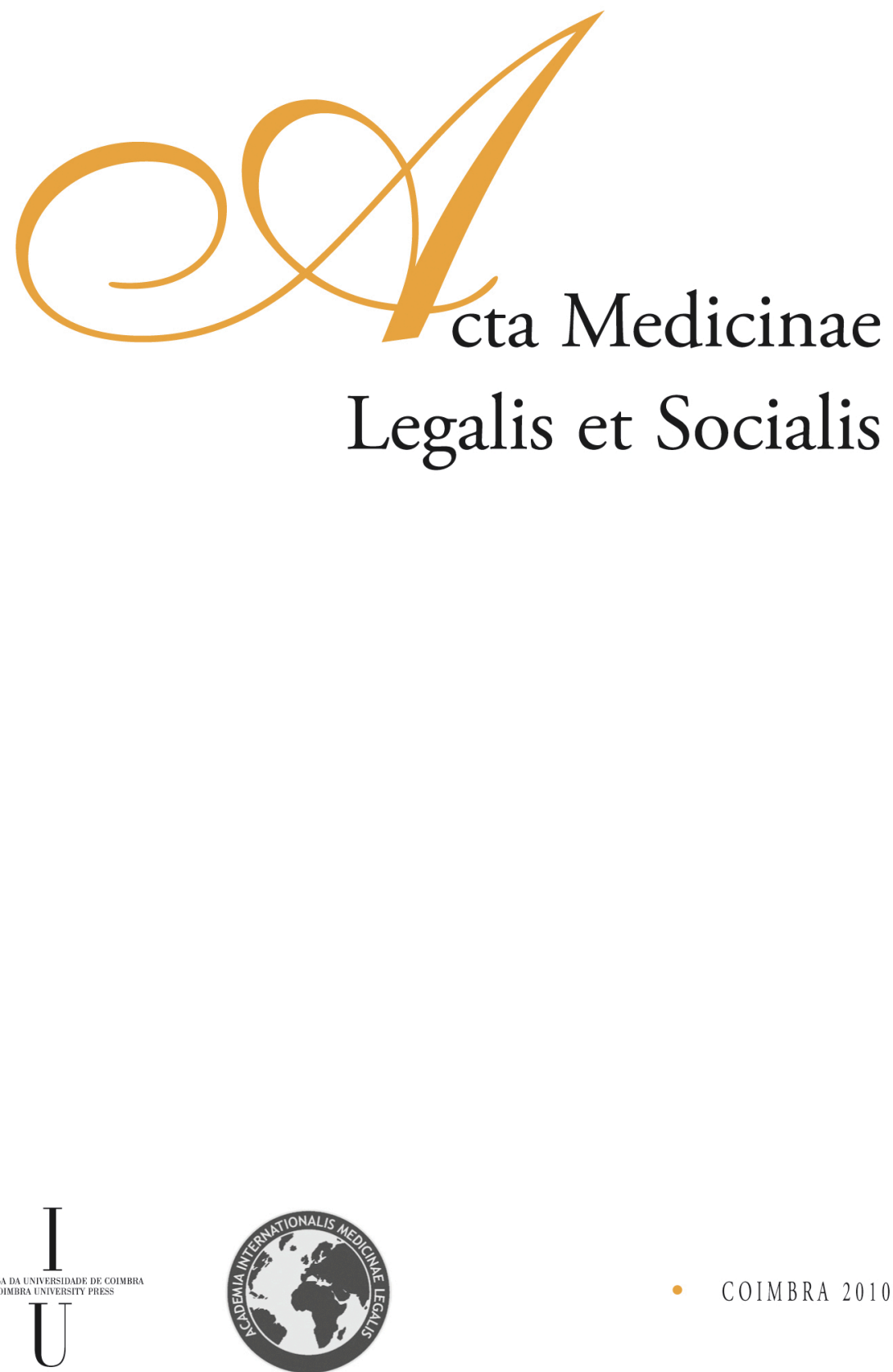


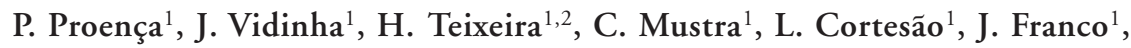 \\ F. Corte-Real ${ }^{1,2}$, D. N. Vieira ${ }^{1,2}$ \\ ${ }^{1}$ Centre Branch of the National Institute of Legal Medicine, Coimbra, Portugal \\ ${ }^{2}$ Faculty of Medicine, University of Coimbra, Portugal
}

\title{
SUICIDE BY DROWNING AFTER BROMAZEPAM INTOXICATION: A CASE REPORT
}

\begin{abstract}
The authors report a case of a floating body recovered from a well. A 62-year-old woman committed suicide by drowning herself in a well. According to information given by her relatives she had a 13-year history of depression and she wanted to commit suicide. Liquid chromatography with electrospray ionization mass spectrometry (LC-ESI-MS) was used to determine bromazepam in blood. Samples were extracted using Oasis ${ }^{\circledR}$ HLB solid-phase cartridges, and separation and quantitation was done using positive-mode electrospray ionization in the single ion monitoring (SIR) mode. Chromatographic separation was achieved using an Atlantis ${ }^{\circledR} \mathrm{T} 3$ column $(2.1 \times 150 \mathrm{~mm}, 5 \mu \mathrm{m})$, eluted in a gradient system with acetonitrile and formic acid $0.1 \%$, at a flow rate of $300 \mu \mathrm{L} / \mathrm{min}$. Quantitation was achieved by the addition of diazepam deuterated (DZP-d5) as internal standard. The compounds were detected monitoring two ions for bromazepam $(\mathrm{m} / \mathrm{z}$ 318 , and $\mathrm{m} / \mathrm{z} 288$ ) and $\mathrm{m} / \mathrm{z} 290$ for the deuterated, DZP-d5.

Toxicological results revealed in blood a toxic concentration of bromazepam of $418 \mathrm{ng} / \mathrm{mL}$. This finding might be important for the interpretation, not of the cause of death (since the drowning was confirmed by autopsy), but for the state of mind of the victim that had, somehow, helped her to committ suicide (concomitant existence of a psychotropic substance).
\end{abstract}

\section{Introduction}

Bromazepam (Bromalex $\AA$, Lexotan $\AA$, Ultramidol@) is an intermediate-acting 1,4-benzodiazepine and is widely prescribed as an anxiolytic, but it also exhibits sedative and hypnotic properties [1]. The literature shows that following a single administration of $12 \mathrm{mg}$ to 10 subjects, an average peak plasma concentration of bromazepam of $131 \mathrm{ng} / \mathrm{ml}$ was achieved between 1 and $4 \mathrm{~h}$, declining with an average half-life of 11.9 h [2].

Bromazepam is metabolised primarily by 3 -hydroxylation and cleavage of the sevenmembered ring, followed by glucuronide conjugation of the hydroxylated metabolites. Intact bromazepam is a major blood constituent, about $2 \%$ of dose is excreted in the $72 \mathrm{~h}$ urine as unchanged bromazepam, $0.4 \%$ as the ring cleavage product, $27 \%$ as conjugated 3-hydroxybromazepam (3-HOB) and $40 \%$ as the hydroxylated and 
conjugated cleavage product [3]. Serum bromazepam therapeutic concentrations are in the range of $80-170 \mathrm{ng} / \mathrm{mL}$. Levels higher than $250 \mathrm{ng} / \mathrm{mL}$ are considered as potentially toxic [4].

Deaths caused by benzodiazepines alone in the absence of other xenobiotics or pathology are uncommon, although some fatal cases have been reported in the literature [5-6].

The authors present a drowning case with bromazepam and an LC-ESI-MS method to detect, confirm and quantify this benzodiazepine in blood samples.

\section{Case report}

A 62-year-old woman committed suicide by drowning herself in a well. She was found by her sister who first saw a bench and her slippers near the well. She lived alone since her parents' death, 13-years ago and according to information given by her relatives, she was under a severe depression and wanted to commit suicide.

At autopsy, an external examination revealed eye congestion. On internal inspection, abundant white foam was observed in the trachea, larynx and bronchi. Swollen lungs, presence of Paultauf's spots, fluid in the stomach, pulmonary edema were observed. The postmortem findings also indicated generalized visceral congestion. No signs of violence were observed.

Blood, liver and kidney samples were submitted to toxicological analysis.

\section{Materials and methods}

\subsection{Chemicals and reagents}

Bromazepam and diazepam-d5 were obtained from Cerilliant (Promochem, France) at a concentration of $1 \mathrm{mg} / \mathrm{ml}$ in methanol. Separate working solutions of bromazepam and diazepam- $\mathrm{d} 5$ were prepared in methanol after appropriate dilutions and were stored at $+4^{\circ} \mathrm{C}$. Formic acid, methanol and acetonitrile were HPLC grade and were purchased from E. Merck (Darmstadt, Germany). Deionized and purified water was obtained using a Milli-Q system (Millipore, Molsheim, France). Oasis ${ }^{\circledR}$ HLB, 3 cc, solid-phase cartridges were purchased from Waters (Milford, MA). The mobile phase was filtered through a $0.20 \mu \mathrm{m}$ filter (Schleicher \& Schuell) and degassed in an ultrasonic bath for $15 \mathrm{~min}$ just before use.

\subsection{Instrumentation}

Liquid chromatography (LC) was performed using a Waters Alliance 2695 separation mode. A $20 \mu \mathrm{L}$ aliquot of the extract was injected onto the column (Atlantis ${ }^{\circledR}$ T3 5 $\mu \mathrm{m}, 2.1 \times 150 \mathrm{~mm}$ ) (Waters). Each 20-min chromatographic run was carried out with a gradient $(10 \%$ acetonitrile, $90 \%$ formic acid, $0.1 \%$ to a ratio $90-10 \%$ at $14 \mathrm{~min}$ ) at a flow rate of $300 \mu \mathrm{L} / \mathrm{min}$. The column temperature was maintained at $35^{\circ} \mathrm{C}$. 
Instrument control, data acquisition and processing were achieved using Waters Empower software (Milford, MA).

Mass spectrometry detection (MS) was carried out on a Waters ZQ 2000 single quadrupole mass spectrometer with an electrospray ionization (ESI) performed in positive mode. Full-scan spectra were recorded from $\mathrm{m} / \mathrm{z} 200-450$, at a scan time of $0.5 \mathrm{~s}$ and an interscan delay of $0.1 \mathrm{~s}$. The other main instrument settings were: capillary voltage $3.5 \mathrm{KV}$; cone voltage $60 \mathrm{~V}$; extractor $4 \mathrm{~V}$; ion energy 0.4 ; source temperature $120^{\circ} \mathrm{C}$; desolvation temperature $350^{\circ} \mathrm{C}$; cone gas $(\mathrm{N} 2)$ flow rate $0 \mathrm{~L} / \mathrm{h}$ and desolvation gas (N2) flow rate $600 \mathrm{~L} / \mathrm{h}$.

Quantitation employed the selected ion-recording mode (SIR) using the $\mathrm{m} / \mathrm{z}$ corresponding to the most abundant product ion $[\mathrm{M}+\mathrm{H}]^{+}$at $m / z 318$ for bromazepam and $m / z 290$ for the internal standard (diazepam-d5). Both SIR and Scan acquisitions were performed in centroide mode.

\subsection{Sample preparation}

Control and calibration samples were prepared by spiking drug-free whole blood samples with standard solutions.

A $1 \mathrm{~mL}$ aliquot of whole blood was spiked with $25 \mu \mathrm{L}$ of internal standard (10 $\mu \mathrm{g} / \mathrm{mL}$ ) and diluted with $2 \mathrm{~mL}$ of deionized water. Then the samples were vortex mixed and centrifuged for at $3000 \mathrm{rpm}$ for $5 \mathrm{~min}$. Extraction cartridges (Oasis ${ }^{\circledR}$ HLB, $3 \mathrm{cc}$ ) were conditioned with $2 \mathrm{~mL}$ of methanol followed by $2 \mathrm{~mL}$ of deionized water. Each sample was loaded through a cartridge. It was then washed with $2 \mathrm{~mL}$ of $5 \%$ methanol in water. After drying under vacuum for $15 \mathrm{~min}$, elution was carried out with $2 \mathrm{~mL}$ of methanol. The eluate was evaporated to dryness under a nitrogen gas flow at $40^{\circ} \mathrm{C}$. The residue was dissolved in $250 \mu \mathrm{L}$ of mobile phase and an aliquot $(20 \mu \mathrm{L})$ was injected into the LC-ESI-MS system.

\section{Results and discussion}

Blood alcohol concentration was measured by Headspace GC-FID. A systematic toxicological drug screening was carried out in blood with a combination of immunoassays and CG-MS analysis. Benzodiazepinas were positive by immunoassays and identified in blood by LC-ESI-MS. Bromazepam was detected, confirmed and quantitated in blood samples. Toxicological results revealed in blood a toxic concentration of bromazepam of $418 \mathrm{ng} / \mathrm{mL}$. No other drugs were found in the postmortem blood samples of presented fatal case. No alcohol was found.

The calibration curves for bromazepam in the blood samples were linear, ranging from 5 to $1000 \mathrm{ng} / \mathrm{mL}\left(\mathrm{r}^{2}=0.9995\right.$, seven calibration points, in triplicate). The detection limit of bromazepam in blood was $1 \mathrm{ng} / \mathrm{mL}(L O D, \mathrm{~S} / \mathrm{N}=3)$ and the lower limit of quantification $(L O Q, \mathrm{~S} / \mathrm{N}=10$ ) was $5 \mathrm{ng} / \mathrm{mL}$ (Table I).

Quantitation employed the selected ion-recording mode (SIR) using the most abundant characteristic ion, $m / z 318$ and the fragment ions, $m / z 288$ and $m / z 209$ for confirmation. SIR mass chromatograms of the bromazepam detected in the blood sample are shown in Fig. 1. 
Bromazepam and its main metabolite (3-HOB, $\mathrm{m} / \mathrm{z} 332, \mathrm{~m} / \mathrm{z} 315$ and $\mathrm{m} / \mathrm{z} 303$ ) were detected in liver. Kidney sample only revealed the presence of bromazepam.

Although several cases of acute bromazepam intoxication have been reported, only few were lethal $[2,7-8]$. The blood concentration of bromazepam found in this fatal case was higher than the reported therapeutic level $(80-170 \mathrm{ng} / \mathrm{mL})$. Levels higher than $250 \mathrm{ng} / \mathrm{mL}$ are considered as potentially toxic.

This finding might be important for the interpretation, not of the cause of death since the drowning was confirmed by autopsy, but for the state of mind of the victim that had, somehow, helped her to commit suicide (concomitant existence of a psychotropic substance).

\section{References}

[1] A. C. Moffat, M.D. Osselton, B. Widdop, Clarke's Analysis of Drugs and Poisons in pharmaceuticals, body fluids, and postmortem materials. $3^{\text {th }}$ ed. The Pharmaceutical Press, 708-709, 2004.

[2] R. C. Baselt, Disposition of toxic drugs and chemicals in man, $7^{\text {th }}$ ed. Biomedical Publications, 124-125, 2004.

[3] J.G. Hardman, A. Goodman. Gilman, and L.E. Limbird, Goodman and Gilman's The Pharmacological Basic of Therapeutics, 9 ${ }^{\text {th }}$ ed. McGraw-Hill, 1996.

[4] Therapeutic and toxic drug concentrations list, last update 05.06.2007, http:// www.tiaft. org/tmembers/ttv/ttv_ab.html.

[5] M. J. Ellenhorn, S. Schonwald, G. Ordog, J. Wassenberg, Ellenhorn's medical toxicology: diagnosis and treatment of human poisoning, $2^{\text {th }} \mathrm{ed}$. Williams and Wilkins, Baltimore, 687-695, 1997.

[6] O. H. Drummer, D. Ranson, Sudden death and benzodiazepines, Am. J. Forensic Med. Pathol., 17: 336-342, 1996.

[7] C. Brehmer, P. X. Hern, A fatal bromazepam poisoning, Bull. Int. Assoc. Forensic Toxicol., 22: 21-22, 1992.

[8] K. Michaud, N. Romain, C. Giroud, C. Brandt, P. Mangin, Hypothermia and undressing associated with non-fatal bromazepam intoxication, Forensic Sci. Int., 124: 112-114, 2001.

\begin{tabular}{|c|c|c|c|c|c|}
\hline \multicolumn{2}{|c|}{$\frac{\text { Selected ions }(\mathrm{m} / \mathrm{z}) \text { and cone }}{\text { voltage }}$} & \multicolumn{2}{|c|}{ Limits $(\mathrm{ng} / \mathrm{mL})$} & \multirow[t]{2}{*}{$\underline{\text { Linearity }}$} & \multirow[t]{2}{*}{$\underline{\mathrm{R}^{2}}$} \\
\hline Quantitation & Confirmation & $L O D$ & $L O Q$ & & \\
\hline 318 & $288 ; 209$ & 1 & 5 & $0.005-1$ & 0.9995 \\
\hline $30 \mathrm{~V}$ & $50 \mathrm{~V}$ & $\mathrm{~S} / \mathrm{N}<3$ & $\mathrm{~S} / \mathrm{N}<10$ & & \\
\hline
\end{tabular}

Table I - Selected ions, $L O D, L O Q$ and linearity range of bromazepam in blood samples. 

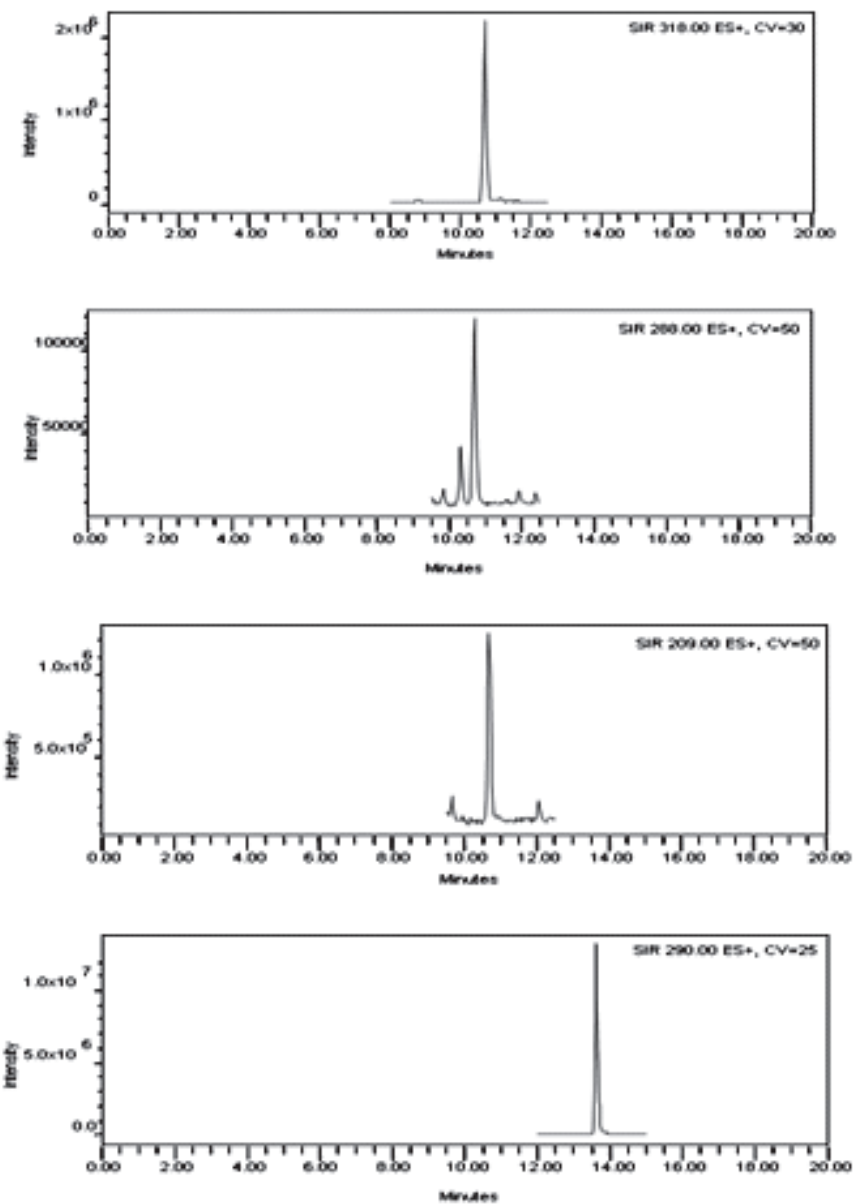

Figure 1 - SIR mass chromatograms of bromazepam in postmortem blood samples. 